\title{
INDEXAÇÃO E RESPONSABILIDADE
}

\section{INDEXATION AND RESPONSIBILITY}

\section{Guilherme Pinto Bravo Neto, TCBC-RJ}

A transmissão do conhecimento ao longo dos séculos permitiu a evolução das ciências e das artes. A invenção da escrita, por volta do ano 3000 a.C., foi essencial para este fim, e já em 1700 a.C. são descritos, no código de Hamurabi, na Mesopotâmia, os primeiros regulamentos da prática da medicina. No Egito do século XVII a.C., o papiro Edwin Smith, um dos mais antigos documentos médicos de que se tem registro, contém referências a inúmeros problemas cirúrgicos. Mas foi Hipócrates, no século V a.C., quem deu início ao estudo racional da prática médica, não baseado em crenças religiosas, e quem redigiu inúmeros tratados que foram agrupados na Coletânea Hipocrática.

Com o progresso da medicina e de sua complexidade, a "experiência pessoal" e as "impressões" dos grandes mestres foram sendo paulatinamente substituídas por trabalhos com metodologia rigorosa e avaliações estatísticas complexas, capazes de assegurar a eficácia de tratamentos ou outras proposições, muitas vezes desmentindo práticas seculares transmitidas por gerações de médicos sem quaisquer embasamentos científicos. Tem início a era da medicina baseada em evidências, com todo seu pragmatismo, seus algoritmos, suas meta-análises, que preenchem boa parte das páginas das mais conceituadas revistas da atualidade.

O valor da contribuição científica de artigos médicos tornou-se condição indispensável para publicação em periódicos respeitados, lembrando que a recíproca é também verdadeira, e periódicos tornaram-se respeitados pela publicação de artigos de alto valor científico. Nos centros mais desenvolvidos, onde a pesquisa consome e gera grandes recursos, as publicações se tornaram veículos de avassaladora dominação científica, com influência marcante, em vários níveis, no mundo globalizado. Em países em desenvolvimento, onde a produção de conhecimento "novo" ainda é baixa em áreas como a medicina, a publicação de artigos em periódicos de impacto tornou- se um desafio, que antes de ser sobrepujado, passou a ser obrigatório para a manutenção de cursos de pósgraduação em grandes centros brasileiros. É, portanto, fundamental que tenhamos opções de publicação em periódicos de elevada visibilidade para que possamos divulgar amplamente nossa produção científica.

A recente inclusão da Revista do Colégio Brasileiro de Cirurgiões na coleção SciELO Brasil torna o periódico mais visível e mais qualificado para divulgar artigos de alto nível, que, em formato eletrônico, terá ampla difusão na América Latina e, em menor grau, em outras regiões do planeta. Esta indexação deverá proporcionar, ainda, impulso para outras indexações ainda mais abrangentes, na medida em que continuemos a divulgar trabalhos de elevado conteúdo científico e mantenhamos critérios já sedimentados de periodicidade, pontualidade, alto nível do Conselho Redatorial e arbitragem por pares (peer review).

Desta forma, o esforço implementado pelo atual Diretório, que se somou aos esforços dos Diretórios anteriores e que foram essenciais para a indexação da revista, representam, na realidade, o início de um trabalho árduo para garantir a progressão que se faz necessária. Precisamos melhorar ainda mais o nível de nossas publicações, e isto deverá ocorrer não só pela captação de melhores trabalhos, num movimento de reciprocidade mencionado anteriormente, mas também pelo maior rigor por parte do nosso Conselho Redatorial na seleção de artigos. A necessidade de se melhorar a produção científica nas universidades brasileiras, a importância das publicações em periódicos de impacto no currículo do professor universitário e o desenvolvimento de centros de excelência não universitários são condições que deverão corroborar para a melhora da qualidade dos trabalhos científicos na área cirúrgica, que contarão, a partir de agora, com a Revista do CBC como um veículo de divulgação de maior amplidão, e como sempre, identificado com o cirurgião brasileiro. 